\title{
Tularemia vaccine development: paralysis or progress?
}

This article was published in the following Dove Press journal:

Vaccine: Development and Therapy

4 May 2016

Number of times this article has been viewed

\section{Raju Sunagar \\ Sudeep Kumar \\ Brian J Franz \\ Edmund J Gosselin}

Center for Immunology and Microbial Disease, Albany Medical College, Albany, NY, USA
Correspondence: Edmund J Gosselin 47 New Scotland Avenue, Center for Immunology and Microbial Disease, Albany Medical College, Albany, NY 12208, USA

Email gossele@mail.amc.edu
Abstract: Francisella tularensis $(\mathrm{Ft})$ is a gram-negative intercellular pathogen and category A biothreat agent. However, despite 15 years of strong government investment and intense research focused on the development of a US Food and Drug Administration-approved vaccine against $F t$, the primary goal remains elusive. This article reviews research efforts focused on developing an $F t$ vaccine, as well as a number of important factors, some only recently recognized as such, which can significantly impact the development and evaluation of Ft vaccine efficacy. Finally, an assessment is provided as to whether a US Food and Drug Administrationapproved $F t$ vaccine is likely to be forthcoming and the potential means by which this might be achieved.

Keywords: Sex bias, media impact, differential protection, cellular immunity, humoral immunity

\section{Introduction}

Fifteen years after the 2001 attacks on the World Trade Center in New York City, when it was recognized that organisms such as Francisella tularensis (Ft) could be utilized as a biothreat agent, a US Food and Drug Administration (FDA)-approved vaccine for tularemia remains an elusive goal. This is despite extensive financial investment since 2001 in research and development of such a vaccine. The question thus remains as to whether an Ft vaccine is still possible. This review discusses what we have learned since 2001, the confounding factors that may have helped to produce for some a sense of paralysis in the tularemia vaccine field, and whether an FDA-approved tularemia vaccine remains plausible.

\section{Microbiology and etiology of Ft}

Based on DNA similarity and fatty acid composition, the genus Francisella has been classified into three species: F. tularensis (Ft), F. philomiragia, and F. hispaniensis. ${ }^{1}$ $F t$ is further classified into five subspecies of Ft tularensis (also called Ft type A), Ft holarctica (Ft type B), Ft novicida, Ft mediasiatica, and a variant of Ft holarctica found in Japan. ${ }^{2}$ In the case of F. novicida, it should also be noted that based on the high degree of genetic relatedness between $F t$ and $F$. novicida, F. novicida was assigned as a subspecies of Ft in 2006. However, there was a formal objection in favor of F. novicida being designated as its own species in $2010,{ }^{3}$ in which it was suggested that the original assignment was based solely on genetic relatedness and did not take into consideration the phenotypic and genomic difference between Ft and F. novicida. However, despite this objection, the original assignment of $F$. novicida 
as a subspecies of $F t$ was reaffirmed. ${ }^{4}$ More importantly, of the aforementioned species, only types A and B are the major causes of human disease, whereas $F$. novicida is virulent in mice but avirulent in humans. ${ }^{5} F$. philomiragia is a muskrat pathogen. Ft type A is a highly virulent organism exclusively found in North America and is associated with rabbits and a wide range of arthropod vectors. ${ }^{6} F t$ type $\mathrm{A}$ is also more genetically diverse and evolutionarily older than the moderately virulent Ft type B. ${ }^{2}$ Furthermore, molecular characterizations have identified two distinct clades or genotypes of $F t$ type A that differ in their geographic location and virulence. ${ }^{7,8}$ In contrast, $F t$ type B is generally less virulent and is associated with semiaquatic rodents, hares, ticks, and mosquitoes. It is widely distributed throughout much of the northern hemisphere and is the only species found in Europe. ${ }^{6}$ In addition, molecular typing studies have identified three distinct biovariants of $F t$ type B that differ in antibiotic resistance pattern and geographic locations in Europe. ${ }^{9}$ The live vaccine strain (LVS) is an attenuated variant of the Ft subspecies holarctica. However, Ft type A represents the greatest concern in terms of bioterrorism and human disease in that it is highly virulent and intradermal (ID) or inhaled exposure to just ten to 50 bacteria can cause severe infection and death. ${ }^{10,11}$

\section{The immune response to $\mathrm{Ft}$ and correlates of protection}

It is generally believed that immune responses to $F t$ are induced through traditional mechanisms of immune response induction, which include Ft antigen (Ag) uptake, processing, and presentation by B-cells, dendritic cells (DCs), macrophages (MØs), and subsequent $F t$-specific T- and B-cell activation. Thus, the key to developing an effective vaccine against $F t$ is a clear understanding of those immune components required for protection. Furthermore, the route of infection, as well as bacterial virulence, will ultimately determine the degree of protection achieved by a given mode of vaccination. Ft can infect the host through multiple routes: ulceroglandular (through skin scratch), pneumonic (through lungs), oropharyngeal (through gastrointestinal tract), oculoglandular (infection through conjunctiva), and typhoidal (ingestion may be the mode of transmission). ${ }^{12-14}$ It is also important to note that although all subspecies of $F t$ have been demonstrated to infect humans, most studies focused on understanding the immune response to Francisella have utilized mice. In addition, it is important to note that the type A strain is highly virulent in both humans and mice..$^{2,15}$ Similarly, type B Ft holarctica strain, which includes Ft LVS, is virulent in both mice and humans, with mice, however, being much more susceptible. ${ }^{5}$

\section{Humoral immunity}

The role of humoral immunity in the resolution of infection and protection against $F t$ remains controversial, in part because of the conventional wisdom asserting that cellular immune responses are more important for protection against intracellular pathogens. ${ }^{16}$ However, a number of investigations have demonstrated that humoral immunity can play a role in protection against tularemia, consistent with the observation that Ft has been shown to have an extracellular phase. ${ }^{16-18}$ Furthermore, studies have demonstrated that both mouse and human antibody $(\mathrm{Ab})$ responses are similar in terms of $\mathrm{Ag}$ recognition, with the $\mathrm{Ab}$ being predominantly directed against bacterial lipopolysaccharides (LPS). In the case of humans, a robust $\mathrm{Ab}$ response is generated within 2 weeks of immunization or infection, while the peak $\mathrm{Ab}$ response in mice is 7 weeks after infection. ${ }^{16,19-22}$ Furthermore, studies have clearly shown a role for both immunoglobulin (Ig) A and IgG in protection. ${ }^{16,19,22-31}$ Specifically, passive immunization of naive mice with immune sera from $F t$ LPS, heat-killed Ft LVS, or live Ft LVS-immunized animals affords protection against a subsequent $F t$ LVS infection. Nevertheless, Ft SchuS4-challenged mice are not protected. ${ }^{16,22,30,31}$ Moreover, passive transfer of Ft-specific IgM or IgG provided protection against Ft LVS infection. ${ }^{25}$ Furthermore, serum isolated from humans immunized with $F t$ LVS induced significant protection in mice against $F t$ LVS infection. ${ }^{29}$ Most significantly, however, passive immunization of naive mice with immune serum from the mice that survived Ft SchuS4 infection following levofloxacin treatment exhibited protection against Ft SchuS4 challenge in recipient mice. ${ }^{27}$ In other studies, passive transfer of $\mathrm{Ab}$ specific for the membrane protein fraction of Ft LVS alone could augment low-dose gentamicin treatment and provide protection against an $F t$ SchuS4 respiratory challenge, when administered on days 1 and 4 post-challenge. ${ }^{32}$ Additional studies supporting a role for Abs demonstrated that vaccineinduced immunity against pulmonary tularemia is lost in IgA-deficient mice. ${ }^{16,23,24,28}$ In the case of IgG-mediated protection, it is also important to note that $\mathrm{Fc} \gamma$ receptors (Fc $\gamma$ Rs) are required. ${ }^{16,22}$ Specifically, Kirimanjeswara et al ${ }^{22}$ demonstrated that intraperitoneal inoculation of naive recipient mice with immune sera from $F t$ LVS-immunized animals could successfully protect recipient wild-type (WT) mice against an IN Ft LVS challenge. The protective capability of the Ft LVS-specific immune sera was, however, lost when 
Fc $\gamma \mathrm{R}$ common $\gamma$-chain knockout (KO) mice were used as naive recipients. ${ }^{22}$

In conclusion, while it is generally accepted that Abs do mediate protection in the case of $F t$ LVS (type B) challenge, in the case of Ft SchuS4 (type A) challenge, the importance of $\mathrm{Ab}$ is more controversial. Specifically, it remains unclear that generation of $\mathrm{Ab}$ alone via vaccination will be sufficient to provide full and consistent protection against Ft type A challenge.

\section{Cell-mediated immunity}

It has been believed for more than 2 decades that cell-mediated immunity (CMI) plays a critical role in protection against tularemia. ${ }^{16}$ This thinking was due, in part, to the intracellular nature of $F t$ infection. Thus, early studies investigating the role of CMI have focused on CD4+ and CD8+ T-cells, ${ }^{33}$ although emerging evidence is also showing critical roles for DCs, MØs, ${ }^{34}$ polymorphonuclear neutrophils (PMNs), and natural killer (NK) cells. ${ }^{35}$

With regard to T-cells, it has also been suggested that T-cells are the primary cell population responsible for mediating immunity against $F t .{ }^{16}$ Specifically, both CD4 and CD8 T-cells can proliferate and produce interferon- $\gamma($ IFN- $\gamma$ ) in response to a number of $F t$ proteins. ${ }^{33}$ Additionally, depletion of CD4 T-cells, CD8 T-cells, or IFN- $\gamma$ abolishes vaccineinduced immunity against type A Ft SchuS4 infection. ${ }^{36,37}$ In addition, studies have demonstrated that passive protection observed when administering $F t$-specific $\mathrm{Ab}$ to naive recipient mice is dependent on IFN- $\gamma$ and mature T-cells, in that mice depleted of IFN- $\gamma$ or athymic nude mice were not protected against $F t$ LVS infection following adoptive transfer of mouse immune sera. ${ }^{16,25}$

Infected $\mathrm{M} \varnothing_{\mathrm{s}}$ are the predominant site of bacterial replication within the host, somewhat surprisingly, depletion of alveolar MØs using liposomal clodronate does not impede disease progression and death in mice infected IN with Ft LVS. ${ }^{22}$ This result is likely due, in part, to Ft's ability to replicate in other host cells, including epithelial cells and DCs. ${ }^{35,38-40}$ Specifically, multiple studies have found that $F t$ can infect DCs, interfere with DC maturation, and thereby dampen the immune response during the first 72 hours of infection, leading to unhampered growth and spread to systemic organs. ${ }^{16,35,39,41}$ Nevertheless, it has also been demonstrated in the clodronate study that alveolar MØs are critical for passive Ab-mediated protection, since when these cells are depleted, protection is lost. ${ }^{22}$ In this regard, it has also been shown that alveolar MØs do internalize and kill $F t$, when treated with IFN- $\gamma$ and immune sera. ${ }^{22}$ Thus,
MØs play a role in pathogen clearance, which is optimal when $F t$-specific Ab and IFN- $\gamma$ are present.

In the case of PMN, their role in resolving $F t$ infection, similar to that of Ab's role in resolving Ft type A infection, is controversial. While Ab-mediated depletion of PMN suggests these cells are essential for surviving a primary intradermal (ID) or intravenous (IV) Ft infection, this is not the case for intranasal (IN) challenge..$^{35,42,43}$ It has been demonstrated that neither depletion nor recruitment of PMN to the lungs of Ft SchuS4 IN-infected mice impacts bacterial burden or survival time. ${ }^{43}$ Interestingly, IFN- $\gamma$-producing PMNs are detectable at the site of infection within 72 hours, suggesting a potentially protective role for cytokines released by these cells. ${ }^{16,35,43,44}$ It has also been demonstrated that Ab-mediated protection of passively transferred $F t$ LVSspecific immune sera is lost when PMNs are depleted and mice are subsequently challenged IN with $F t$ LVS. ${ }^{22}$

NK cells are an early responder to $F t$ infection and thus thought to be an early source of IFN- $\gamma^{45,46}$ Furthermore, NK cells are key for regulating hepatic granuloma formation, which helps in controlling bacterial spread. ${ }^{47}$ Interestingly, NK cell depletion decreases mean survival time following primary infection but does not affect vaccine-induced immunity, since fewer NK cells are recruited to the lung of immunized and challenged mice compared to unimmunized controls. ${ }^{23,45}$ This suggests that while NK cells are early responders to infection and produce IFN- $\gamma$, they are only necessary following a primary exposure of naive individuals.

In conclusion, with regard to the aforementioned cells and vaccine development, it appears clear that the induction of memory T-cells, and in particular IFN- $\gamma$-producing T helper 1 (Th1) cells, is likely to be key to developing an effective vaccine strategy against $F t$. In support of this contention, studies have also shown that while both $\mathrm{Ab}$ and IFN- $\gamma$ can be critical for vaccine-induced protection, ${ }^{24}$ the need for Ab can be overcome, when IFN- $\gamma$ levels are sufficiently high. ${ }^{28}$ Nevertheless, evidence also suggests that $\mathrm{Ab}$ can play a protective role by supplementing the protective impact of IFN- $\gamma$ in vaccine-induced protection against Ft type A infection.

\section{The immune response in human Ft infection and vaccination}

The human immune response to $F t$ infection and vaccination has been reviewed elsewhere. ${ }^{48}$ Briefly, in the case of natural infection, $F t$-specific IgM, IgG, and IgA Abs are detectable $\sim 2$ weeks after infection. Similar to $F t$ infection in mice, the majority of the $\mathrm{Ab}$ response is directed to Ft $\mathrm{LPS}^{21}$ 
Also similar to that observed in mice, ex vivo production of Th1-type cytokines such as IFN- $\gamma$, TNF- $\alpha$, and IL- 2 by CD 4 and CD8 T-cells is observed by restimulated lymphocytes obtained from tularemia-infected individuals. ${ }^{49,50}$ Similar to natural infection, in the case of vaccination utilizing Ft LVS administered via scarification, $F t$-specific IgM, IgA, and IgG Abs are detected in serum 2 weeks post vaccination, while lymphocytes from vaccinated individuals restimulated ex vivo produce Th1-type cytokines, in particular IFN- $\gamma .^{20,51}$ However, it is also important to note that in the case of $\mathrm{Ab}$ responses, similar to mice infected with $\mathrm{Ft}$, the generation of anti-Ft Abs is not necessarily predictive of protection against subsequent infection with virulent $F t$ type A organisms.

\section{Ft vaccine strategies}

Due to its high infectivity, high mortality rate at a very low infectious dose (ten to 50 organisms), and its ability to be aerosolized, $F t$ has been designated a category A biothreat agent by the Centers for Disease Control and Prevention (CDC). The need for a vaccine is further emphasized by the fact that although WT strains of Ft do respond to antibiotic treatment, which includes fluoroquinolones, tetracyclines, and the aminoglycosides, ${ }^{52} \mathrm{Ft}$ strains have been engineered to be antibiotic resistant. ${ }^{14,15}$ Furthermore, despite extensive research and investment over the last 15 years, there remains no FDA-approved vaccine. Thus, there remains a critical need for an effective $F t$ vaccine. Various strategies, which have been used to accomplish this, are discussed subsequently.

\section{Live attenuated vaccines}

Live attenuated vaccines have shown the greatest promise thus far, although concerns about reversion remain a significant roadblock to their use as an Ft vaccine. A number of live attenuated vaccine candidates were made from $\mathrm{Ft}$ holarctica by the Soviets in the 1940s and 1950s. ${ }^{53}$ However, Ft LVS is the only vaccine available in the West to combat tularemia. ${ }^{54}$ However, although $F t$ LVS does provide partial protection against a type A challenge in humans, ${ }^{54}$ it is not licensed in the USA, primarily due to the uncertainty regarding its source of attenuation and it instability in culture..$^{53,55}$ However, despite the fact $F t$ LVS is not approved as a vaccine, considerable additional money and effort have been devoted to the development of a safe and efficacious attenuated $F t$ vaccine using Ft LVS (Table 1), F. novicida (Table 2), and Ft SchuS4 (Table 3). Our own studies (unpublished data) and that of others ${ }^{56}$ using a $\operatorname{SodB}$ mutant of Ft LVS have clearly demonstrated the potential for generating protection against a primary infection, as well as high-dose secondary exposure to Ft SchuS4, when immunizing with this attenuated organism (Figure 1). Thus, should a fully protective attenuated vaccine be developed, in which safety concerns are eliminated or further minimized, possibly via multiple targeted/well-defined mutations, this approach could still produce a strong $F t$ vaccine candidate.

\section{Inactivated $\mathrm{Ft}$ vaccines}

Over 70 years ago, Foshay and his research group attempted to develop the first killed vaccine for tularemia. ${ }^{57,58}$ Although Foshay's vaccine preparations were able to protect nonhuman primates against Ft SchuS4, ${ }^{53}$ they exhibited significant toxicity, including the generation of necrotic lesions. In addition, there was no significant protection observed in laboratory workers or in subsequent controlled animal trials. ${ }^{57,58}$ Consistent with the latter study, more recent attempts at developing a killed $F t$ vaccine have also met with mixed success.

Table I Ft LVS-based live attenuated vaccines

\begin{tabular}{|c|c|c|c|c|c|c|c|}
\hline $\begin{array}{l}\text { Vaccine strain } \\
\text { (Ft LVS) }\end{array}$ & $\begin{array}{l}\text { Growth } \\
\text { medium }\end{array}$ & $\begin{array}{l}\text { Animal } \\
\text { model }\end{array}$ & Sex & $\begin{array}{l}\text { Vaccine dose } \\
\text { (route) }\end{array}$ & $\begin{array}{l}\text { Ft LVS challenge } \\
\% \text { protection } \\
\text { (dose, route) }\end{array}$ & $\begin{array}{l}\text { Ft SchuS4 challenge \% } \\
\text { protection (dose, route) }\end{array}$ & References \\
\hline Ft LVS & MHB & C57BL/6 & $F$ & I00 CFU (IN) & ND & $100 \%$ (25 CFU, IN) & 131 \\
\hline SodB & MHB & C57BL/6 & $M / F$ & $\mathrm{I}, 200 \mathrm{CFU}(\mathrm{IN})$ & $100 \%\left(1.2 \times 10^{6} \mathrm{CFU}, \mathrm{IN}\right)$ & $40 \%(103 \mathrm{CFU}, \mathrm{IN})$ & 56 \\
\hline$C l p B$ & $\begin{array}{l}\mathrm{BHI} \\
\mathrm{CDM}\end{array}$ & C57BL/6 & $\mathrm{F}$ & $5 \times 10^{4} \mathrm{CFU}(\mathrm{IN})$ & $100 \%\left(5 \times 10^{3} \mathrm{CFU}, \mathrm{IN}\right)$ & I0\% (30 CFU, IN) & 132 \\
\hline emrAl & MHB & C57BL/6 & $\mathrm{F}$ & $10^{6} \mathrm{CFU}(\mathrm{IN})$ & $100 \%\left(10^{7} \mathrm{CFU}, \mathrm{IN}\right)$ & I5\% (I7 CFU, IN) & 87 \\
\hline CapB & MHB & $\mathrm{BALB} / \mathrm{c}$ & $\mathrm{F}$ & $10^{6} \mathrm{CFU}(\mathrm{IN})$ & ND & $100 \%\left(10 \mathrm{LD}_{100}\right.$, aerosol $)$ & 133 \\
\hline$c l p B$ & NA & $\mathrm{BALB} / \mathrm{c}$ & NA & $5 \times 10^{4} \mathrm{CFU}(\mathrm{IN})$ & ND & $30 \%(86 \mathrm{CFU}, \mathrm{IN})$ & 134 \\
\hline$d s b A$ & McLeod & $\mathrm{BALB} / \mathrm{c}$ & $\mathrm{F}$ & $10^{6} \mathrm{CFU}(\mathrm{SC})$ & ND & $\begin{array}{l}100 \%(100 \mathrm{CFU}, \mathrm{SC}) \\
50 \%(100 \mathrm{CFU}, \mathrm{IN})\end{array}$ & 135 \\
\hline$w b t A$ & $\mathrm{CHAH}$ & $\mathrm{BALB} / \mathrm{c}$ & M & $1.5 \times 10^{7} \mathrm{CFU}(\mathrm{IN})$ & $100 \%\left(25 \mathrm{LD}_{50}, \mathrm{IN}\right)$ & $25 \%(10$ CFU, IN $)$ & 136 \\
\hline Wzy & MHB & $\mathrm{BALB} / \mathrm{c}$ & M & $2.4 \times 10^{7} \mathrm{CFU}(\mathrm{IN})$ & $100 \%\left(1.2 \times 10^{5} \mathrm{CFU}, \mathrm{IN}\right)$ & 84\% (8 CFU, IN) & 137 \\
\hline
\end{tabular}

Abbreviations: Ft, Francisella tularensis; LVS, live vaccine strain; MHB, Mueller Hinton Broth; F, female; ND, not determined; IN, intranasal; $M$, male; BHI, brain heart infusion; CDM, Chamberlain's defined medium; NA, not available; SC, subcutaneous; $\mathrm{CHAH}$, cysteine heart agar containing $2 \%$ hemoglobin; $\mathrm{LD}_{50}$, median lethal dose; $\mathrm{LD}_{100}$, absolute lethal dose. 
Table 2 F. novicida-based live attenuated vaccines

\begin{tabular}{|c|c|c|c|c|c|c|c|}
\hline $\begin{array}{l}\text { Vaccine strain } \\
\text { (F. novicida) }\end{array}$ & $\begin{array}{l}\text { Growth } \\
\text { medium }\end{array}$ & Animal model & Sex & $\begin{array}{l}\text { Vaccine dose } \\
\text { (route) }\end{array}$ & $\begin{array}{l}\text { Ft LVS challenge \% } \\
\text { protection } \\
\text { (dose, route) }\end{array}$ & $\begin{array}{l}\text { Ft SchuS4 challenge \% } \\
\text { protection } \\
\text { (dose, route) }\end{array}$ & References \\
\hline ig/B: fopC & TSB & C57BL/6 & NA & $10^{3} \mathrm{CFU}$ (oral) & $80 \%\left(3.5 \times 10^{4} \mathrm{CFU}, \mathrm{IN}\right)$ & ND & 138 \\
\hline \multirow[t]{4}{*}{$\lg \mid \mathrm{D}$} & TSB & $\mathrm{BALB} / \mathrm{c}$ & NA & $9.7 \times 10^{8} \mathrm{CFU}(\mathrm{IN})$ & ND & $0 \%\left(10^{3} \mathrm{CFU}, \mathrm{IN}\right)$ & 139 \\
\hline & CDM & & & & & & \\
\hline & & Fischer rats (344) & $\mathrm{F}$ & $10^{5} \mathrm{CFU}(\mathrm{IT})$ & ND & $100 \%\left(10^{4} \mathrm{CFU}, \mathrm{IT}\right)$ & \\
\hline & & NHP & $M / F$ & $10^{8} \mathrm{CFU}(\mathrm{BR})$ & ND & $83 \%\left(10^{3} \mathrm{CFU}\right.$, aerosol $)$ & \\
\hline ig/B & TSB & Fischer rats (344) & $\mathrm{F}$ & $10^{7} \mathrm{CFU}$ (oral or IT) & ND & $50 \%\left(\sim 10^{4} \mathrm{CFU}\right.$, oral or IT $)$ & 140 \\
\hline \multirow[t]{2}{*}{ ig/B:fljB } & TSB & $\mathrm{BALB} / \mathrm{c}$ & NA & $10^{3} \mathrm{CFU}$ (oral) & $83 \%\left(8.5 \times 10^{4} \mathrm{CFU}, \mathrm{IN}\right)$ & ND & $|4|$ \\
\hline & & Fischer rats (344) & NA & $10^{7} \mathrm{CFU}$ (oral) & ND & $83 \%\left(10^{4}, \mathrm{IT}\right)$ & \\
\hline
\end{tabular}

Abbreviations: F. novicida, Francisella novicida; Ft, Francisella tularensis; LVS, live vaccine strain; TSB, tryptic soy broth medium; NA: not available; IN, intranasal; ND, not determined; CDM, Chamberlain's defined medium; F, female; IT, intrathecal; NHP, nonhuman primate (cynomolgus macaque); M, male; BR, bonchoscopy route.

While incorporation of Freund's adjuvant into killed (phenol-merthiolate treated) Ft LVS or Ft SchuS4 did not augment $F t$ vaccine efficacy, ${ }^{59}$ a heat-killed $F t$ LVS vaccine formulated with IL-12 expressed in a vasicular stomatitis virus-based vector generated enhanced $F t$ LVS clearance versus nonadjuvanted vaccine. ${ }^{31}$ In another study, mucosal vaccination with inactivated $F t(\mathrm{i} F t)$ LVS (paraformaldehyde or UV treated) in combination with IL-12 conferred $>90 \%$ protection against lethal $F t$ LVS challenge. This protection was correlated with enhanced bacterial clearance, reduced tissue inflammation, and increased $F t$-specific serum IgG and
$\mathrm{Ig} \mathrm{A} \mathrm{Ab}$ responses. However, this strategy proved ineffective at protecting against an Ft SchuS4 challenge. ${ }^{23}$ Similarly, while Eyles et $\mathrm{al}^{60}$ showed that intramuscular immunization of $\mathrm{BALB} / \mathrm{c}$ mice with iFt adjuvanted with immune-stimulating complexes (ISCOMS) or preformed ISCOMS admixed with immunostimulatory $\mathrm{CpG}$ oligonucleotides provided robust protection against respiratory challenges with Ft holarctica HN63, the same vaccine formulation did not protect against a low-dose aerosol challenge with $F t$ SchuS4.

An alternative approach to the use of adjuvants involved the use of FcyR-targeted monoclonal antibody (mAb)-iFt

Table $3 \mathrm{Ft}$ SchuS4-based live attenuated vaccines

\begin{tabular}{|c|c|c|c|c|c|c|c|}
\hline $\begin{array}{l}\text { Vaccine strain } \\
\text { (Ft SchuS4) }\end{array}$ & $\begin{array}{l}\text { Growth } \\
\text { medium }\end{array}$ & Animal model & Sex & $\begin{array}{l}\text { Vaccine dose } \\
\text { (route) }\end{array}$ & $\begin{array}{l}\text { Ft LVS } \\
\text { challenge \% } \\
\text { protection } \\
\text { (dose, route) }\end{array}$ & $\begin{array}{l}\text { Ft SchuS4 challenge } \\
\% \text { protection } \\
\text { (dose, route) }\end{array}$ & References \\
\hline \multirow[t]{4}{*}{ FTTII 03} & MHA & C57BL/6 & NA & $10^{7}-10^{8} \mathrm{CFU}(\mathrm{IN})$ & ND & $100 \%(37-68 \mathrm{CFU}, \mathrm{IN})$ & 142 \\
\hline & TSB & & & & & & \\
\hline & CDM & & & & & & \\
\hline & & $\mathrm{BALB} / \mathrm{c}$ & NA & $10^{7}-10^{8} \mathrm{CFU}(\mathrm{IN})$ & ND & 75\% (37-68 CFU, IN) & \\
\hline \multirow[t]{3}{*}{$c l p B$} & $\mathrm{CHAH}$ & $\mathrm{C} 57 \mathrm{BL} / 6$ & $\mathrm{~F}$ & $10^{5} \mathrm{CFU}(\mathrm{ID})$ & ND & $0 \%(\mathrm{I} 00 \mathrm{CFU}, \mathrm{IN})$ & 114 \\
\hline & MHB & & & & & & \\
\hline & & $\mathrm{BALB} / \mathrm{c}$ & $\mathrm{F}$ & $10^{5} \mathrm{CFU}$ (ID) & ND & $80 \%(I 00 \mathrm{CFU}, \mathrm{IN})$ & \\
\hline \multirow[t]{3}{*}{ ig/D } & TSB & $\mathrm{BALB} / \mathrm{c}$ & NA & $4.8 \times 10^{6} \mathrm{CFU}(\mathrm{IN})$ & $0 \%(\mathrm{IN})$ & ND & 139 \\
\hline & CDM & & & & & & \\
\hline & & Fischer rats (344) & & $10^{7} \mathrm{CFU}(\mathrm{IT})$ & ND & $50 \%\left(10^{4} \mathrm{CFU}, \mathrm{IT}\right)$ & \\
\hline FTT0369 & MHB & $\mathrm{BALB} / \mathrm{c}$ & $\mathrm{F}$ & $50 \mathrm{CFU}$ (IN or ID) & ND & $90 \%(50 \mathrm{CFU}, \mathrm{IN}) 100 \%$ & 143 \\
\hline FTTI 676 & & & & & ND & $(50 \mathrm{CFU}, \mathrm{ID})$ & \\
\hline \multirow{2}{*}{ сарB } & CDM & $\mathrm{BALB} / \mathrm{c}$ & $\mathrm{F}$ & $10^{4} \mathrm{CFU}(\mathrm{SC})$ & ND & $60 \%\left(10^{3}, \mathrm{SC}\right)$ & 144 \\
\hline & BCGA & & & & & & \\
\hline \multirow[t]{2}{*}{ FTT09/8 } & $\mathrm{CHAH}$ & $\mathrm{BALB} / \mathrm{c}$ & $\mathrm{F}$ & $10^{5} \mathrm{CFU}(\mathrm{ID})$ & ND & $100 \%(500, \mathrm{SC})$ & 145 \\
\hline & MHB & & & & & & \\
\hline \multirow[t]{2}{*}{ ggt } & CDM & $\mathrm{BALB} / \mathrm{c}$ & & $8.75 \times 10^{5} \mathrm{CFU}(\mathrm{SC})$ & & $100 \%\left(10^{2}, \mathrm{SC}\right)$ & 146 \\
\hline & BCGA & & $\mathrm{F}$ & & ND & & \\
\hline guaBA & $\mathrm{BHI}$ & NZW rabbit & $\mathrm{F}$ & $10^{9} \mathrm{CFU}$ (scarification) & ND & $27 \%-36 \%\left(10^{4}\right.$, aerosol $)$ & 147 \\
\hline aroD & & & & & & & \\
\hline
\end{tabular}

Note: Data from Reed et al. ${ }^{147}$

Abbreviations: Ft, Francisella tularensis; LVS, live vaccine strain; TSB, tryptic soy broth; CDM, Chamberlain's defined medium; NA: not available; IN, intranasal; ND, not determined; $\mathrm{CHAH}$, cysteine heart agar containing 2\% hemoglobin; MHB, Mueller Hinton Broth; F, female; ID, intradermal; IT, intrathecal; BCGA, blood cysteine glucose agar; SC, subcutaneous; BHI, brain heart infusion; NZW, New Zealand White; MHA, Mueller Hinton Agar. 

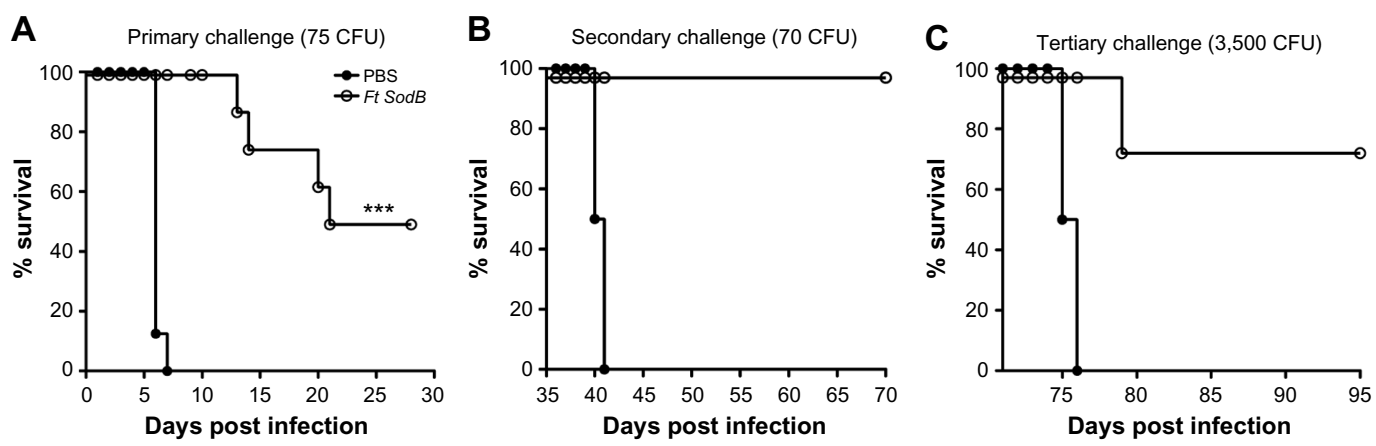

Figure I Acute and convalescent protection of C57BL/6 mice vaccinated with a live attenuated Ft vaccine (SodB mutant) and subsequently challenged with high-dose Ft SchuS4.

Notes: C57BL/6 female mice were immunized ID with either PBS or $\sim 1 \times 10^{3} \mathrm{CFU}$ of attenuated Ft LVS SodB mutant grown in BHI medium in $50 \mu \mathrm{L}$ on day 0 and boosted IN on day 21 with either $20 \mu \mathrm{L}$ of PBS or $\sim 1 \times 10^{3}$ CFU of attenuated Ft LVS SodB mutant. Mice were then challenged IN on day 42 with 75 CFU of Ft SchuS4 ( $60-70 \times$ LD $\left._{50}\right)$ and subsequently monitored for 30 days for survival (A). 35 days after primary challenge survivors were rechallenged IN with 70 CFU of SchuS4 and subsequently monitored for 30 days for survival (B). 35 days after secondary challenge survivors were again rechallenged IN with 3,500 CFU of Ft SchuS4 and subsequently monitored again for 30 days for survival $(\mathbf{C})$. **** $\leq 0.001$.

Abbreviations: Ft, Francisella tularensis; ID, intradermal; PBS, phosphate-buffered saline; IN, intranasal; LVS, live vaccine strain; LD ${ }_{50}$, median lethal dose; CFU, colony forming unit; $\mathrm{BHI}$, brain heart infusion.

immune complexes (ICs). Such ICs, when administered IN, induced full protection against $F t$ LVS challenge and up to $50 \%$ protection against Ft SchuS4 challenge. ${ }^{24}$ Consistent with this increased protection, enhanced humoral and cellular immune responses were also observed, as compared to i $F t$ administered alone. ${ }^{24}$ Bitsaktsis et $\mathrm{a}^{28}$ also demonstrated that the addition of CTB adjuvant to iFt could similarly induce complete protection of mice challenged with $F t$ LVS and partial protection of $F t$ SchuS4-challenged mice. The observed protection also correlated with enhanced production of IFN$\gamma$, as was also the case in the studies using mAb-iFt ICs as immunogen. ${ }^{24}$ Thus, while killed vaccines are less likely to generate a strong cellular immune response, as apposed to attenuated vaccines, ${ }^{23}$ successful protection against an $\mathrm{Ft}$ type A strain was observed. Importantly, it is also believed that killed vaccines provide a significant safety advantage versus attenuated vaccines.

\section{Subunit vaccines}

From the perspective of manufacture, safety, and FDA approval, an ideal vaccine against tularemia would use a recombinant subunit approach, which would eliminate the potential for reversion that could occur with live attenuated vaccines and significantly reduce the potential for toxicity, which could occur with killed vaccines. However, to date, no Ft proteins capable of generating strong protective immunity against an $F t$ type A challenge have been identified. . $^{15,33,61-63}$ Additionally, while LPS purified from $F t$ LVS, or as a part of a crude membrane fraction, has been utilized as a vaccine candidate and offers some protection against $F t$ LVS infection, LPS has proven ineffective as a protective immunogen against Ft SchuS4 challenge, making the development of a subunit vaccine against $F t$ difficult at this time ${ }^{5,19,30,64-67}$ Additional efforts to develop such a vaccine have included vaccination of mice with O-Ag capsular polysaccharide in the presence of adjuvant or chemically conjugated to bovine serum albumin, which enhanced protection against $F t$ LVS but failed to protect mice against aerosol challenge with more virulent strains of $F t^{64,68}$ Additionally, while immunization of mice with $F t$ LVS LPS in the presence of PorB, a porin produced by Neisseria meningitidis and a TLR2 ligand, enhanced the survival of mice challenged with $F t$ LVS, additional studies are still required to determine whether this approach is effective against the more virulent subspecies of $F t .{ }^{69}$ Furthermore, an LPS immunogen derived from $F t$ SchuS4 did not generate protective immunity against a subsequent $F t$ SchuS4 challenge, although it did provide protection when mice were challenged with $\mathrm{Ft}$ holarctica. ${ }^{67,70}$

Other bacterial components have also been investigated for use in a subunit vaccine but with limited success. Tul4, an Ft surface lipoprotein, when administered alone did not generate immune responses capable of controlling Ft LVS bacterial replication following IV challenge. ${ }^{71}$ In addition, immunizing mice with Tul4 and DnaK, an Ft heat shock protein, in the presence of GPI (a semi-synthetic triterpene glycoside adjuvant) could also induce significant protection of mice against a respiratory challenge with Ft LVS. However, the effectiveness of this approach in protecting against an Ft SchuS4 challenge was not reported. ${ }^{72}$ Other studies utilized intraperitoneal immunization with Ft outer membrane proteins emulsified in Freund's adjuvant, which did protect $\sim 50 \%$ of mice challenged IN with Ft SchuS4, although the specific protein responsible for this protection was not identified ${ }^{66}$ Because of the abundance of the Ft outer membrane 
protein A (FopA) and the knowledge that FopA-specific Abs are found in sera of recovering patients, Hickey et $\mathrm{al}^{73}$ sought to determine whether FopA would provide protection against $F t$ challenge. Although FopA immunization in the presence of IL-12 and aluminum hydroxide did protect mice against IN or ID Ft LVS challenge, it did not provide protection against an ID Ft SchuS4 challenge. ${ }^{73}$ Thus, while numerous studies have focused on utilizing/identifying Ft-Ag that could be incorporated into an Ft subunit vaccine, the key requirement for a subunit vaccine, identification of a single Ag that confers effective protection against type A Ft strain, still has not been met.

\section{Bacterial and viral vector vaccines}

Attenuated microorganisms such as bacteria and viruses have been successfully used as vehicles to deliver vaccine Ags. Furthermore, the advent of genetic engineering has facilitated the alteration of pathogenic microorganisms, thereby attenuating them and allowing them to serve as vehicles for heterologous Ags. In addition, intrinsic characteristics of microorganisms, such as LPS and other pathogen-associated molecular pattern molecules, enable such vehicles to evoke strong innate immune responses, which can in turn guide a robust adaptive immune response against the target $\mathrm{Ag}(\mathrm{s}) /$ organism. ${ }^{74,75}$ A number of microbes have been developed for this purpose: Salmonella, Listeria monocytogenes, ${ }^{76}$ Vibrio cholerae, lactic acid bacteria, ${ }^{77}$ Bordetella pertussis,${ }^{78}$ and Mycobacterium bovis, ${ }^{79}$ and viruses, such as adenovirus, retrovirus, lentivirus, cytomegalovirus, and Sendai virus. ${ }^{75}$ However, to date, only a few attempts have been made to develop a tularemia vaccine using microbial vectors. Jia et al used L. monocytogenes to deliver a number of Ft proteins. However, only the expression of IglC by this organism led to $100 \%$ protection against lethal Ft LVS challenge. However, the results of the type A challenge are open to interpretation, in that although immunization with the vector-expressing IglC provided $80 \%-100 \%$ protection, immunization with the vector control, which lacked the Ags, generated 40\%-50\% protection. ${ }^{80}$ In another study, Fulop et al ${ }^{81}$ used Salmonella enterica serovar Typhimurium to deliver Ft FopA protein. However, this vaccine failed to induce significant protection against $F t$ LVS challenge. More recently, Banik et al used TMV as a vaccine vehicle for OmpA, DnaK, and Tul4 Ags. They incorporated these Ags into the TMV vector either together in a single virion (monoconjugate vaccine) or in separate virions (multiconjugate vaccine), which were then mixed to introduce all three Ags into the host. Both strategies elicited moderate levels of protection against a high-dose challenge with Ft LVS. ${ }^{82}$ Thus, despite some promising results with $F t$ LVS challenge, this approach has also failed to provide an effective vaccine strategy against Ft type A strains. As with subunit vaccines, this failure may also primarily stem from the lack of identified Ft Ags capable of inducing protection against the highly virulent type A Ft strains.

\section{Fc $\gamma R$-targeted vaccines}

Targeted vaccines direct an immunogen to a specific immunological target, such as a specific cell type or receptor, in order to stimulate an enhanced host immune response. One of the primary functions of Fc $\gamma \mathrm{R}$ is to mediate internalization (phagocytosis), processing, and presentation of Ag. ${ }^{24,83,84}$ Consistent with this function, Rawool et $\mathrm{al}^{24}$ demonstrated that paraformaldehyde $\mathrm{i} F t$, when administered $\mathrm{IN}$ in the form of $\mathrm{mAb}-\mathrm{i} F t \mathrm{IC}$, induces full protection against $F t$ LVS challenge and partial protection against $F t$ SchuS4 challenge, as apposed to that of $\mathrm{i} F t$ alone, which provided $50 \%$ and $0 \%$ protection, respectively. Consistent with the increased protection, humoral and cellular immune responses were also enhanced, and the use of traditional adjuvant was not required. ${ }^{24}$ In regard to mechanisms involved in the Fc $\gamma \mathrm{R}-$ enhanced protection against Ft challenge, Iglesias et al demonstrated that when administered IN, the transport of $\mathrm{i} F t$ from the nasal passage to the nasal associated lymphoid tissue is significantly enhanced, when in the form of mAb$\mathrm{i} F t$. In addition, the rate of $\mathrm{i} F t$ binding and internalization by antigen-presenting cells (APCs) is also significantly enhanced, as well as the length of time over which the $\mathrm{i} F t$ is presented by APCs to T-cells is extended. ${ }^{85}$ These studies were also followed up by more extensive mechanistic studies focused on in vivo responses to IN immunization with $\mathrm{mAb}$-i $F t$ versus $\mathrm{i} F t$. Specifically, Bitsaktsis et $\mathrm{al}^{86}$ demonstrated that as apposed to IN administration of $\mathrm{i} F t$ alone, direct targeting of $\mathrm{i} F t$ to Fc $\gamma \mathrm{R}$ via $\mathrm{mAb}-\mathrm{i} F t$ IC elicits a higher frequency of activated DCs within the lung of mAb-iFt-immunized mice following Ft challenge. The number of IFN- $\gamma$ producing effector memory CD4 T-cells is also increased in this case, via an IL12-dependent mechanism. ${ }^{86}$ Finally, studies by Suresh et $\mathrm{al}^{87}$ also indicate that similar Fc $\gamma \mathrm{R}$ targeting of a live attenuated $F t$ vaccine can result in improved vaccine efficacy when utilizing a live attenuated $\mathrm{mAb}-F t$ IC vaccine followed by $F t$ SchuS4 challenge. Specifically, the authors demonstrated that an oxidant-sensitive $F t$ LVS mutant (emrA1) administered IN could extend median time to death following a subsequent Ft SchuS4 challenge, as compared to unvaccinated controls. ${ }^{87}$ They went on to show that time to death was further extended when the emrA1 mutant bacteria was delivered in the form of mAb-emrA1 Ft IC, providing additional evidence for 
the benefits of FcyR-targeted vaccines in the generation of enhanced immunity against $F t{ }^{87}$ Nevertheless, it is also important to note that $\mathrm{mAb}-\mathrm{i} F t$ IC can engage both activat-

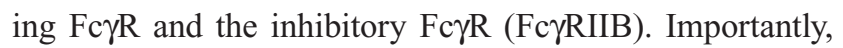
the latter could thus limit the level of immune enhancement/ protection, generated by $\mathrm{mAb}-\mathrm{i} F t$ immunogen. In this regard, using Fc $\gamma$ RIIB KO mice, Franz et $\mathrm{al}^{88}$ demonstrated this was in fact the case, suggesting that if an FcyR-targeted vaccine could be developed, which engages the activating Fc $\gamma \mathrm{R}$, but not Fc $\gamma$ RIIB, the enhanced immunity and protection observed with $\mathrm{mAb}-\mathrm{i} F t$ IC could be significantly improved.

\section{DNA vaccines}

The primary advantages of DNA vaccines are that they are simple and relatively cheap to manufacture, as compared to conventional vaccines (whole cell or protein based). In addition, DNA has a higher shelf life and can be stored at room temperature, making its transport and storage more cost effective. ${ }^{89}$ More importantly, DNA vaccines induce both Ab-mediated immunity and CMI, ${ }^{89}$ the latter being critical for protection against tularemia. ${ }^{56}$ However, despite the apparent advantages of DNA vaccines over conventional vaccines, efforts to develop a DNA vaccine against tularemia are limited. In one such study, a DNA vaccine using T-cell epitopes (identified by their reactivity to T-cells of previously infected humans) induced proinflammatory cytokines and protection against $F t$ LVS challenge. However, protection against type A $F t$ infection by this vaccine was not determined..$^{90}$ A similar study using another set of epitopes also generated protection against lethal Ft LVS challenge but failed to protect mice against a type A Ft challenge. The latter vaccine included CD8 T-cell epitopes, which induced a strong CD8 T-cell response but only limited CD4 T-cell responses. ${ }^{91}$

\section{Major factors influencing Ft vaccine efficacy and vaccination studies}

In addition to the $\mathrm{Ag} /$ immunogen utilized, a number of other key factors influence $F t$ vaccine efficacy, which include bacterial strain, growth conditions of the attenuated or killed vaccine and/or challenge strain, the genetic background of the animal model, and sex. Furthermore, the lack of experimental consistency and consideration of such factors (Tables 1-3) have only served to muddy the water in terms of the successful development of a tularemia vaccine.

\section{Impact of bacterial strain}

Bacterial strain dictates not only virulence but also, when used as an attenuated or killed vaccine, the level of protection generated. The best example in regard to strain differences impacting virulence is Ft LVS (type B) versus Ft SchuS4 (type A). While Ft LVS is lethal in mice, it is not lethal in humans and has thus been used as an attenuated vaccine for humans. ${ }^{54}$ In contrast, Ft SchuS4 is highly virulent in mice and humans. ${ }^{8}$ However, despite extensive investigations over the last 15 years, the precise reasons for this difference remain unknown. More recent studies have also revealed differing levels of virulence between the type A subpopulations A1a, $\mathrm{A} 1 \mathrm{~b}$, and A2. Human infections due to A1b resulted in significantly higher mortality (24\%) than those caused by A1a (4\%) and A2 (0\%). ${ }^{8}$ These observations are further supported by primary infection studies using C57BL/6 mice, in which mice infected with $\mathrm{A} 1 \mathrm{~b}$ died significantly earlier than those infected with strains A1a or A2. ${ }^{92,93}$ A similar tendency has been noticed following vaccination in which mice infected with two distinct type A strains, Ft FSC033 and Ft SchuS4, exhibited increased susceptibility of both naive and $F t$ LVSimmunized mice (BALB/c and C57BL/6) by Ft FSC033 versus Ft SchuS4 ${ }^{94}$ Furthermore, a more recent study showed that subcutaneous vaccination with a sublethal dose of a highly virulent $F t$ LVS strain is capable of protecting BALB/c mice against respiratory challenge with a virulent type $\mathrm{A}$ strain. ${ }^{95,96}$ Similar results were observed using C57BL/6 mice vaccinated with two different strains of Ft LVS, which differed in their median lethal dose $\left(\mathrm{LD}_{50}\right)$. Specifically, $100 \%$ of mice vaccinated with the highly virulent strain of $F t$ LVS survived Ft SchuS4 challenge, whereas mice vaccinated with a less virulent strain of Ft LVS strain all succumb to Ft SchuS4 infection. Consistent with the latter observation, earlier studies by Eigelsbach et al reported the existence of two different colony variants of the prototypical virulent type A Ft SchuS4 and type B Ft LVS strains. These variants were identified on the basis of colony morphology (rough colonies versus smooth colonies) and their appearance (blue versus gray)..$^{53,55,97}$ In the latter case, WT SchuS4 and Ft LVS appear blue and the variants gray. These phenotypic differences were also linked to differences in virulence, as well as immunologic properties. In regard to virulence, the $F t$ LVS gray variants exhibited less virulence, as well as being less efficacious in protection against the virulent $F t$ type A strain challenge studies compared to blue variants. ${ }^{53,55,98}$ However, as noted throughout this review, the most important aspect of these strain differences is that the majority of protective $F t$ vaccines using an $F t$ LVS type B challenge fail to generate similar protection, when using an $F t$ type A challenge. Nevertheless, current evidence tends to indicate that differences in virulence are largely due to intrinsic properties 
of the bacterial strains and are not directly related to host sex, susceptibility, genetics, or otherwise failed immune responses. ${ }^{8}$ However, regardless of the cause of the strain differences in virulence, the use of an Ft type A challenge to accurately identify potential vaccine candidates and evaluate $F t$ vaccine efficacy is generally required.

\section{Impact of bacterial growth medium}

Immunogens used as attenuated or killed vaccines must first be grown in vitro. However, culture medium has been shown to have a profound impact on the set of proteins expressed by microbes. ${ }^{99}$ Thus, the choice of medium can significantly alter the antigenic composition and efficacy of whole cell-based attenuated and killed vaccines. For example, $M$. bovis (BCG) used in human vaccination is grown in Sauton medium. ${ }^{100}$ However, research laboratories use Middlebrook 7H9 medium. ${ }^{101}$ BCG grown in Middlebrook 7H9 and Sauton media exhibits different protein expression profiles and different levels of sensitivity to reactive nitrogen intermediates. ${ }^{102}$ This difference is also reflected in its protective efficacy, as BCG grown in Middlebrook $7 \mathrm{H} 9$ medium confers better protection compared to BCG grown in Sauton medium. Moreover, the elevated protection generated by BCG grown in Middlebrook $7 \mathrm{H} 9$ medium is also associated with higher numbers of Mycobacteria-specific TH17 cells and higher Ab levels. ${ }^{101}$ Similarly, a number of other microbes have been reported to differentially express immunogenic molecules, depending on the growth medium. ${ }^{103-107}$ Ft grown in vitro in Mueller Hinton Broth (MHB) expresses a distinct set of genes as compared to those obtained from tissues or $\mathrm{M} \varnothing_{\mathrm{s}}$ following $\mathrm{Ft}$ infection. ${ }^{108} \mathrm{In}$ addition, MHB-grown Ft (Ft-MHB) can induce production of select proinflammatory cytokines, while Ft obtained from $F t$-infected animals or MØs exhibit a reduced ability to do so. ${ }^{109,110}$ Importantly, Ft grown in brain heart infusion (BHI) medium in vitro (Ft-BHI) exhibits a protein expression and proinflammatory cytokine pattern more closely resembling that of Ft obtained from DCs or MØs in vivo. ${ }^{99,108} F t$-BHI and $F t$-MHB also differ in their ability to interact with complement and Ft LPS-specific Abs, with Ft-MHB being more reactive. The altered immune responses to $F t$-MHB versus $F t$-BHI can be attributed to differential protein expression, surface carbohydrates expression, and structural integrity. ${ }^{99}$ With this in mind, we have investigated the efficacy of $F t$ LVS-based vaccines generated in MHB versus BHI and have found that while $F t$-MHB is more protective in mice challenged with $F t$ LVS (manuscript in preparation), $F t$-BHI is a more protective immunogen following an Ft SchuS4

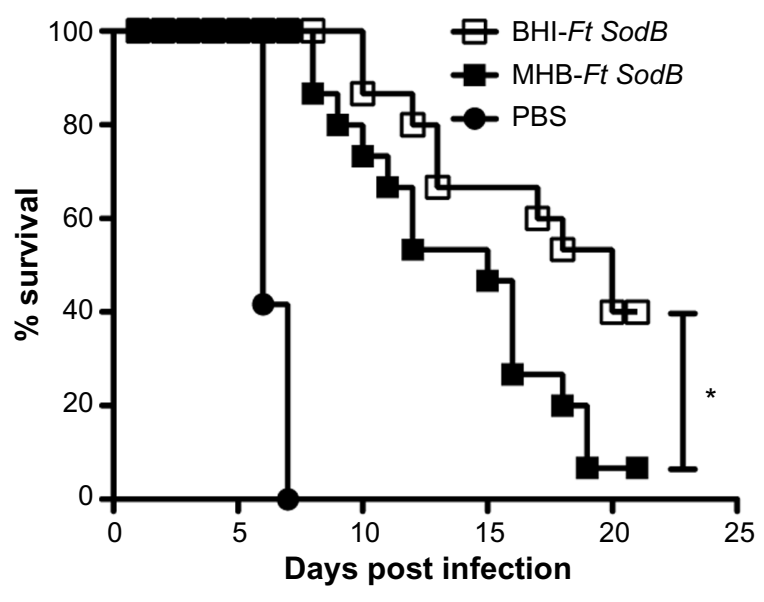

Figure 2 Impact of growth medium on Ft vaccine efficacy.

Notes: Challenge studies were conducted as follows: C57BL/6 male and female mice were immunized IN with Ft SodB mutant of Ft LVS grown in either BHI or MHB media. Mice were immunized on day 0 and boosted on day 21 , then challenged IN on day 42 with 33 CFUs of Ft SchuS4 and subsequently monitored for 25 days for survival. $* P \leq 0.05$.

Abbreviations: Ft, Francisella tularensis; IN, intranasal; LVS, live vaccine strain; $\mathrm{LD}_{50}$, median lethal dose; PBS, phosphate-buffered saline; $\mathrm{BHI}$, brain heart infusion; $\mathrm{MHB}$, Mueller Hinton Broth; CFU, colony forming unit.

challenge (Figure 2). These findings once again emphasize the importance of challenge strain, as well as the growth medium, when evaluating $F t$ vaccine efficacy.

\section{Impact of animal model}

\section{The murine model}

The murine model is of particular interest in this regard, since the majority of the studies focused on Ft vaccination and infection are done using the mouse model, and in particular $\mathrm{C} 57 \mathrm{BL} / 6$ or BALB/c mice. The genetic background of the individual strains of mice can have a significant impact on the outcome of both the immune response and survival, in murine models of infectious disease and vaccination. ${ }^{111-113}$ More specifically, it has been demonstrated that C57BL/6 mice are more susceptible to Ft infection and less easily protected against challenge with the highly virulent type A Ft, as apposed to BALB/c mice. Specifically, ID immunization of BALB/c mice with Ft LVS generates protective immunity against a successive ID challenge but not a respiratory challenge with type A $F t .{ }^{96}$ In contrast, similarly, immunized C57BL/6 mice are not protected against either ID or respiratory challenge with the same $F t$ challenge organism. ${ }^{114}$ Similarly, ID vaccination with SchuS4-clpB (a heat shock protein mutant) protects $\mathrm{BALB} / \mathrm{c}$ but not $\mathrm{C} 57 \mathrm{BL} / 6$ mice from a subsequent respiratory challenge with Ft SchuS4. The increased susceptibility of C57BL/6 mice to tularemia compared to that of $\mathrm{BALB} / \mathrm{c}$ mice has been attributed to the increased IFN $\gamma$ and pulmonary IL-17 levels observed 
in the lungs of C57BL/6 mice. ${ }^{114}$ There are numerous factors, in addition to increased IFN $\gamma$ and pulmonary IL-17 levels, observed in the lungs of C57BL/6 mice that may also explain the differences in susceptibility of vaccinated $\mathrm{C} 57 \mathrm{BL} / 6$ versus $\mathrm{BALB} / \mathrm{c}$ mice. More severe tissue damage is observed in $\mathrm{C} 57 \mathrm{BL} / 6$ mice than $\mathrm{BALB} / \mathrm{c}$ mice, following pulmonary infection. ${ }^{115}$ It has also been demonstrated that C57BL/6 mice favor the development of a Th2 phenotype in the lung versus the more protective Th1 response. ${ }^{111,116} \mathrm{It}$ is also possible that $F t$ LVS vaccination fails to induce and maintain sufficient numbers of Ag-specific memory T-cells in the lungs of C57BL/6 mice. ${ }^{36,117}$ Collectively, this suggests that BALB/c mice, following vaccination, develop a more protective immune response to subsequent $F t$ infection as compared to that of $\mathrm{C} 57 \mathrm{BL} / 6$ mice. An additional example of this finding has also been observed with $\mathrm{C} 3 \mathrm{H} / \mathrm{HeN}$ versus $\mathrm{BALB} / \mathrm{c}$ mice. Intradermal immunization with a sublethal dose of $F t$ LVS produced reduced survival in $\mathrm{C} 3 \mathrm{H} / \mathrm{HeN}$ versus BALB/c mice, receiving an aerosol Ft SchuS4 challenge. Consistent with the latter, BALB/c mice immunized ID with the SchuS4-clpB mutant also exhibited increased survival as compared to $\mathrm{C} 3 \mathrm{H} / \mathrm{HeN}$ mice. However, in contrast to the aforementioned observation, oral priming and boosting of $\mathrm{C} 3 \mathrm{H} / \mathrm{HeN}$ mice with SchuS4-clpB mutant resulted in significantly longer survival than that of BALB/c mice following an aerosol Ft SchuS4 challenge. ${ }^{118}$ Whether such differences help or hinder $F t$ vaccine development is likely to depend on the approach. By studying such differences, one may more easily identify correlates of protection. However, the more limited the genetic diversity of the animal model being used, in particular as it applies to major histocompatibility complex Class I and Class II expression, the more likely one may fail to identify the vaccines that are most efficacious in an outbred population, such as humans. ${ }^{119}$

\section{Additional animal models}

The majority of Ft research has been, and continues to be, carried out in mice. However, vaccine approval will ultimately require studies be verified in additional animal models. In this regard, an extensive review of such animal models for tularemia has been written. ${ }^{120}$ These animal models include monkey, rat, rabbit, guinea pig, and marmoset. ${ }^{120,121}$ In the aforementioned review, it was concluded that significantly more information on how species, including the rat, rabbit, and guinea pig, respond to $F t$ infection was needed, including a database containing clinical, pathological, and microbiological information, in order to effectively assess strengths and weaknesses of each animal model. In addition, each animal model has specific advantages and disadvantages, which must be considered in the context of the specific goals of animal studies being conducted.

\section{Impact of sex}

It is well established that sex-dependent host factors can significantly impact susceptibility to infection. Multiple studies by various research groups have reported sex-based susceptibility to numerous pathogens and infectious diseases. In general, males of many species are more susceptible than females to bacterial, viral, and fungal infections. ${ }^{122-124}$ However, studies on sex bias in tularemia infection have not been published. Nevertheless, clinical incidence and progression of tularemia in endemic areas has been shown to be significantly higher in males than in females in all age-groups except children (aged 5-9 years). While this may reflect, in part, differences in pathogen exposure through hunting and outdoor professional activities (CDC, http://www.cdc.gov/tularemia/statistics/ agesex.html), ${ }^{125}$ in male versus female susceptibility could also be a contributing factor. We have observed for the first time that while both naive male and female C57BL6 mice are equally susceptible to Ft LVS infection, prior immunization with $\mathrm{i} F t$ or live $F t$ vaccine results in a sex-based immune response and protection in the case of both $F t \mathrm{LVS}^{126}$ and Ft SchuS4 challenge (Figure 3). Specifically, vaccinated male mice develop severe clinical disease and exhibit a significantly higher mortality rate, which correlates with increased tissue destruction, a higher bacterial burden, and weight loss, as compared to immunized female mice. Importantly, this implies that tularemia vaccine efficacy will vary based on sex, which has been observed in clinical trials involving other infectious agents. ${ }^{127-130}$ Thus, development of a successful vaccine against tularemia will require an understanding of the impact sex has on vaccine-induced protection against this organism, with sex differences necessarily being a serious consideration in any future tularemia vaccine development studies.

\section{Paralysis or progress: what does the future hold for Ft vaccine development?}

Despite 15 years of intense research focused on the development of an effective vaccine against the highly virulent type A $F t$, a fully protective, FDA-approved vaccine remains elusive. While attenuated vaccines have provided the most promising results, with a relatively large selection of potential candidates, concerns over safety and in particular reversion, represent significant impediments to the licensure of an attenuated $F t$ vaccine. Some promising results have 

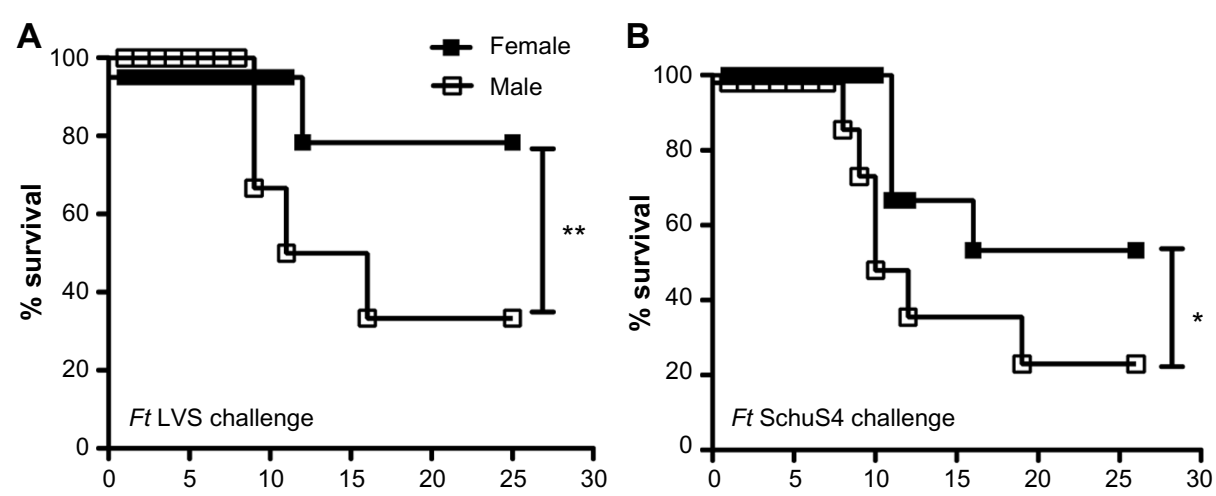

Figure 3 Impact of sex on Ft vaccine efficacy.

Notes: Challenge studies were conducted as follows: C57BL/6 male and female mice were immunized IN with either $20 \mu \mathrm{L}$ of vehicle (PBS) or $20 \mu \mathrm{L}$ of 75 ng of ift on day 0 and boosted on day 21 . Mice were then challenged IN on day 35 with I,500 CFU ( $\left.2 \times L_{50}\right)$ of Ft LVS and subsequently monitored for 25 days for survival (A). C57BL/6 male and female mice were immunized ID with either PBS or $\sim 1 \times 10^{3}$ CFU of attenuated Ft LVS SodB mutant in $50 \mu \mathrm{L}$ day 0 and boosted IN on day 21 with either $20 \mu \mathrm{L}$ of PBS or $\sim 1 \times 10^{3}$ CFU of attenuated Ft LVS SodB mutant. Mice were then challenged IN on day 42 with 33 CFU of Ft SchuS4 and subsequently monitored for 30 days for survival (B). $* P \leq 0.05 . * * P \leq 0.01$.

Abbreviations: Ft, Francisella tularensis; IN, intranasal; PBS, phosphate-buffered saline; iFt, inactivated Ft; LD ${ }_{50}$, median lethal dose; LVS, live vaccine strain; ID, intradermal; CFU, colony forming unit.

also been obtained with killed vaccines, in particular when targeting iFt to Fc $\gamma \mathrm{R}$ IN. However, a number of limitations remain to be overcome in this regard as well. First, 100\% protection against the type A strain of Ft (SchuS4) has not been achieved in this case. Furthermore, the formation of $\mathrm{mAb}-\mathrm{i} F t$ IC can vary significantly from batch to batch, and, as a result, the degree of protection observed can also vary significantly, also leading to significant difficulties with regard to vaccine reproducibility and consequently FDA approval. Thus, in this case, it will be necessary to devise an FcyR-targeting vaccine strategy, which can be more easily produced, is more well defined, and in addition engages activating Fc $\gamma \mathrm{R}$ without engaging the inhibitory Fc $\gamma \mathrm{R}$ (FcrRIIB). In fact, such a vaccine for Ft is currently being developed in our laboratory. In regard to subunit vaccines, this represents the ideal approach in terms of cost, safety, and production and could be accomplished using either a protein or DNA vaccine approach. However, the primary limiting factor in both cases is the lack of an identified protective Ft Ag to incorporate into such a vaccine. Given the lack of progress over the last 15 years in this regard, the incorporation of multiple Ft Ags may provide an alternative means of generating an effective subunit vaccine. Thus, despite the absence of success thus far, a number of viable options still exist to produce a fully protective $F t$ vaccine. Furthermore, a number of published studies, many of which are listed in Tables 1-3, and Figures 1-3 presented in this review demonstrate protection against $F t$ type A challenge following vaccination is possible.

With regard to future studies focused on Ft vaccine development, it is also clear that a number of important factors, such as bacterial strain, growth medium, the genetics of the animal model being used, and sex, can impact protection and must be considered. As indicated in Tables 1-3, these factors vary widely between studies and laboratories and may explain inconsistencies in protection studies observed between laboratories. Thus, it will ultimately be necessary to identify the optimal conditions in each of these cases and consistently use those conditions in evaluating $F t$ vaccine efficacy.

\section{Conclusion}

Given the large number of studies that have generated some level of protection against the type A strain of $F t$ and the many options still available to improve $F t$ vaccine efficacy, progress is being made and it would appear likely that an effective vaccine against $F t$ will be forthcoming, although additional money, time, and research effort will be required.

\section{Acknowledgments}

This work was supported by the National Institutes of Health (NIH) (PO1 AI056320 and RO1 AI100138). The contents of this article are solely the responsibility of the authors and do not necessarily represent the official views of the NIH.

\section{Disclosure}

The authors report no conflicts of interest in this work.

\section{References}

1. Forsman M, Sandstrom G, Sjostedt A. Analysis of 16S ribosomal DNA sequences of Francisella strains and utilization for determination of the phylogeny of the genus and for identification of strains by PCR. Int J Syst Bacteriol. 1994;44(1):38-46. 
2. Svensson K, Larsson P, Johansson D, Bystrom M, Forsman M, Johansson A. Evolution of subspecies of Francisella tularensis. J Bacteriol. 2005;187(11):3903-3908.

3. Tindall BJ, Rossello-Mora R, Busse HJ, Ludwig W, Kampfer P. Notes on the characterization of prokaryote strains for taxonomic purposes. Int J Syst Evol Microbiol. 2010;60(pt 1):249-266.

4. Huber B, Escudero R, Busse HJ, et al. Description of Francisella hispaniensis sp. nov., isolated from human blood, reclassification of Francisella novicida (Larson et al. 1955) Olsufiev et al. 1959 as Francisella tularensis subsp. novicida comb. nov. and emended description of the genus Francisella. Int J Syst Evol Microbiol. 2010;60(pt 8):1887-1896.

5. Ellis J, Oyston PC, Green M, Titball RW. Tularemia. Clin Microbiol Rev. 2002;15(4):631-646.

6. Keim P, Johansson A, Wagner DM. Molecular epidemiology, evolution, and ecology of Francisella. Ann N Y Acad Sci. 2007;1105:30-66.

7. Farlow J, Wagner DM, Dukerich M, et al. Francisella tularensis in the United States. Emerg Infect Dis. 2005;11(12):1835-1841.

8. Kugeler KJ, Mead PS, Janusz AM, et al. Molecular epidemiology of Francisella tularensis in the United States. Clin Infect Dis. 2009;48(7):863-870.

9. Gyuranecz M, Birdsell DN, Splettstoesser W, et al. Phylogeography of Francisella tularensis subsp. holarctica, Europe. Emerg Infect Dis. 2012;18(2):290-293.

10. Saslaw S, Carhart S. Studies with tularemia vaccines in volunteers. III. Serologic aspects following intracutaneous or respiratory challenge in both vaccinated and nonvaccinated volunteers. Am J Med Sci. 1961;241:689-699.

11. Saslaw S, Eigelsbach HT, Wilson HE, Prior JA, Carhart S. Tularemia vaccine study. I. Intracutaneous challenge. Arch Intern Med. 1961;107:689-701.

12. Evans ME, Gregory DW, Schaffner W, McGee ZA. Tularemia: a 30-year experience with 88 cases. Medicine. 1985;64(4):251-269.

13. Avery FW, Barnett TB. Pulmonary tularemia. A report of five cases and consideration of pathogenesis and terminology. Am Rev Respir Dis. 1967;95(4):584-591.

14. Dennis DT, Inglesby TV, Henderson DA, et al. Tularemia as a biological weapon: medical and public health management. JAMA. 2001;285(21):2763-2773.

15. Oyston PC, Sjostedt A, Titball RW. Tularaemia: bioterrorism defence renews interest in Francisella tularensis. Nat Rev Microbiol. 2004;2(12):967-978.

16. Kirimanjeswara GS, Olmos S, Bakshi CS, Metzger DW. Humoral and cell-mediated immunity to the intracellular pathogen Francisella tularensis. Immunol Rev. 2008;225:244-255.

17. Forestal CA, Malik M, Catlett SV, et al. Francisella tularensis has a significant extracellular phase in infected mice. J Infect Dis. 2007;196(1):134-137.

18. Yu JJ, Raulie EK, Murthy AK, Guentzel MN, Klose KE, Arulanandam BP. The presence of infectious extracellular Francisella tularensis subsp. novicida in murine plasma after pulmonary challenge. Eur J Clin Microbiol Infect Dis. 2008;27(4):323-325.

19. Dreisbach VC, Cowley S, Elkins KL. Purified lipopolysaccharide from Francisella tularensis live vaccine strain (LVS) induces protective immunity against LVS infection that requires B cells and gamma interferon. Infect Immun. 2000;68(4):1988-1996.

20. Waag DM, McKee KT Jr, Sandstrom G, et al. Cell-mediated and humoral immune responses after vaccination of human volunteers with the live vaccine strain of Francisella tularensis. Clin Diagn Lab Immunol. 1995;2(2):143-148.

21. Koskela P, Salminen A. Humoral immunity against Francisella tularensis after natural infection. J Clin Microbiol. 1985;22(6):973-979.

22. Kirimanjeswara GS, Golden JM, Bakshi CS, Metzger DW. Prophylactic and therapeutic use of antibodies for protection against respiratory infection with Francisella tularensis. J Immunol. 2007;179(1):532-539.

23. Baron SD, Singh R, Metzger DW. Inactivated Francisella tularensis live vaccine strain protects against respiratory tularemia by intranasal vaccination in an immunoglobulin A-dependent fashion. Infect Immun . 2007;75(5):2152-2162.
24. Rawool DB, Bitsaktsis C, Li Y, et al. Utilization of Fc receptors as a mucosal vaccine strategy against an intracellular bacterium, Francisella tularensis. J Immunol. 2008;180(8):5548-5557.

25. Rhinehart-Jones TR, Fortier AH, Elkins KL. Transfer of immunity against lethal murine Francisella infection by specific antibody depends on host gamma interferon and T cells. Infect Immun. 1994;62(8):3129-3137.

26. Mara-Koosham G, Hutt JA, Lyons CR, Wu TH. Antibodies contribute to effective vaccination against respiratory infection by type A Francisella tularensis strains. Infect Immun. 2011;79(4):1770-1778.

27. Klimpel GR, Eaves-Pyles T, Moen ST, et al. Levofloxacin rescues mice from lethal intra-nasal infections with virulent Francisella tularensis and induces immunity and production of protective antibody. Vaccine. 2008;26(52):6874-6882.

28. Bitsaktsis C, Rawool DB, Li Y, Kurkure NV, Iglesias B, Gosselin EJ. Differential requirements for protection against mucosal challenge with Francisella tularensis in the presence versus absence of cholera toxin B and inactivated F. tularensis. J Immunol. 2009;182(8):4899-4909.

29. Drabick JJ, Narayanan RB, Williams JC, Leduc JW, Nacy CA. Passive protection of mice against lethal Francisella tularensis (live tularemia vaccine strain) infection by the sera of human recipients of the live tularemia vaccine. Am J Med Sci. 1994;308(2):83-87.

30. Fulop M, Mastroeni P, Green M, Titball RW. Role of antibody to lipopolysaccharide in protection against low- and high-virulence strains of Francisella tularensis. Vaccine. 2001;19(31):4465-4472.

31. Lavine CL, Clinton SR, Angelova-Fischer I, et al. Immunization with heat-killed Francisella tularensis LVS elicits protective antibodymediated immunity. Eur J Immunol. 2007;37(11):3007-3020.

32. Sutherland MD, Goodyear AW, Troyer RM, Chandler JC, Dow SW, Belisle JT. Post-exposure immunization against Francisella tularensis membrane proteins augments protective efficacy of gentamicin in a mouse model of pneumonic tularemia. Vaccine. 2012;30(33):4977-4982.

33. Sjostedt A, Eriksson M, Sandstrom G, Tarnvik A. Various membrane proteins of Francisella tularensis induce interferon-gamma production in both CD4+ and CD8+ T cells of primed humans. Immunology. 1992;76(4):584-592.

34. Fortier AH, Polsinelli T, Green SJ, Nacy CA. Activation of macrophages for destruction of Francisella tularensis: identification of cytokines, effector cells, and effector molecules. Infect Immun. 1992;60(3):817-825.

35. Steiner DJ, Furuya Y, Metzger DW. Host-pathogen interactions and immune evasion strategies in Francisella tularensis pathogenicity. Infect Drug Resist. 2014;7:239-251.

36. Wu TH, Hutt JA, Garrison KA, Berliba LS, Zhou Y, Lyons CR. Intranasal vaccination induces protective immunity against intranasal infection with virulent Francisella tularensis biovar A. Infect Immun. 2005;73(5):2644-2654.

37. Wayne Conlan J, Shen H, Kuolee R, Zhao X, Chen W. Aerosol-, but not intradermal-immunization with the live vaccine strain of Francisella tularensis protects mice against subsequent aerosol challenge with a highly virulent type A strain of the pathogen by an alphabeta $\mathrm{T}$ cell- and interferon gamma- dependent mechanism. Vaccine. 2005;23(19):2477-2485.

38. Jones CL, Napier BA, Sampson TR, Llewellyn AC, Schroeder MR, Weiss DS. Subversion of host recognition and defense systems by Francisella spp. Microbiol Mol Biol Rev. 2012;76(2):383-404.

39. Bosio CM, Dow SW. Francisella tularensis induces aberrant activation of pulmonary dendritic cells. J Immunol. 2005;175(10): 6792-6801.

40. Hall JD, Craven RR, Fuller JR, Pickles RJ, Kawula TH. Francisella tularensis replicates within alveolar type II epithelial cells in vitro and in vivo following inhalation. Infect Immun. 2007;75(2): 1034-1039.

41. Bar-Haim E, Gat O, Markel G, Cohen H, Shafferman A, Velan B. Interrelationship between dendritic cell trafficking and Francisella tularensis dissemination following airway infection. PLoS Pathog. 2008;4(11):e1000211. 
42. Sjostedt A, Conlan JW, North RJ. Neutrophils are critical for host defense against primary infection with the facultative intracellular bacterium Francisella tularensis in mice and participate in defense against reinfection. Infect Immun. 1994;62(7):2779-2783.

43. KuoLee R, Harris G, Conlan JW, Chen W. Role of neutrophils and NADPH phagocyte oxidase in host defense against respiratory infection with virulent Francisella tularensis in mice. Microbes Infect. 2011;13(5):447-456.

44. De Pascalis R, Taylor BC, Elkins KL. Diverse myeloid and lymphoid cell subpopulations produce gamma interferon during early innate immune responses to Francisella tularensis live vaccine strain. Infect Immun. 2008;76(9):4311-4321.

45. Lopez MC, Duckett NS, Baron SD, Metzger DW. Early activation of NK cells after lung infection with the intracellular bacterium, Francisella tularensis LVS. Cell Immunol. 2004;232(1-2):75-85.

46. Gosselin EJ, Gosselin DR, Lotz SA. Natural killer and CD8 T cells dominate the response by human peripheral blood mononuclear cells to inactivated Francisella tularensis live vaccine strain. Hum Immunol. 2005;66(10):1039-1049.

47. Bokhari SM, Kim KJ, Pinson DM, Slusser J, Yeh HW, Parmely MJ. NK cells and gamma interferon coordinate the formation and function of hepatic granulomas in mice infected with the Francisella tularensis live vaccine strain. Infect Immun. 2008;76(4):1379-1389.

48. Cowley SC, Elkins KL. Immunity to Francisella. Front Microbiol. 2011;2:26.

49. Koskela P, Herva E. Cell-mediated immunity against Francisella tularensis after natural infection. Scand J Infect Dis. 1980;12(4): 281-287.

50. Surcel HM, Syrjala H, Karttunen R, Tapaninaho S, Herva E. Development of Francisella tularensis antigen responses measured as T-lymphocyte proliferation and cytokine production (tumor necrosis factor alpha, gamma interferon, and interleukin-2 and -4) during human tularemia. Infect Immun. 1991;59(6):1948-1953.

51. El Sahly HM, Atmar RL, Patel SM, et al. Safety, reactogenicity and immunogenicity of Francisella tularensis live vaccine strain in humans. Vaccine. 2009;27(36):4905-4911.

52. Hepburn MJ, Simpson AJ. Tularemia: current diagnosis and treatment options. Expert Rev Anti Infect Ther. 2008;6(2):231-240.

53. Eigelsbach HT, Downs CM. Prophylactic effectiveness of live and killed tularemia vaccines. I. Production of vaccine and evaluation in the white mouse and guinea pig. J Immunol. 1961;87:415-425.

54. Hornick RB, Eigelsbach HT. Aerogenic immunization of man with live tularemia vaccine. Bacteriol Rev. 1966;30(3):532-538.

55. Hartley G, Taylor R, Prior J, et al. Grey variants of the live vaccine strain of Francisella tularensis lack lipopolysaccharide O-antigen, show reduced ability to survive in macrophages and do not induce protective immunity in mice. Vaccine. 2006;24(7):989-996.

56. Bakshi CS, Malik M, Mahawar M, et al. An improved vaccine for prevention of respiratory tularemia caused by Francisella tularensis SchuS4 strain. Vaccine. 2008;26(41):5276-5288.

57. Foshay L. A comparative study of the treatment of tularemia with immune serum, hyperimmune serum and streptomycin. Am J Med. 1946;1:180-188.

58. Foshay L, Hesselbrock WH, Wittenberg HJ, Rodenberg AH. Vaccine prophylaxis against tularemia in man. Am J Public Health Nations Health. 1942;32(10):1131-1145.

59. Nutter JE. Effect of vaccine, route, and schedule on antibody response of rabbits to Pasteurella tularensis. Appl Microbiol. 1969;17(3):355-359.

60. Eyles JE, Hartley MG, Laws TR, Oyston PC, Griffin KF, Titball RW. Protection afforded against aerosol challenge by systemic immunisation with inactivated Francisella tularensis live vaccine strain (LVS). Microb Pathog. 2008;44(2):164-168.

61. Bevanger L, Maeland JA, Naess AI. Agglutinins and antibodies to Francisella tularensis outer membrane antigens in the early diagnosis of disease during an outbreak of tularemia. J Clin Microbiol. 1988;26(3):433-437.
62. Havlasova J, Hernychova L, Halada P, et al. Mapping of immunoreactive antigens of Francisella tularensis live vaccine strain. Proteomics. 2002;2(7):857-867.

63. Sjostedt A, Sandstrom G, Tarnvik A. Several membrane polypeptides of the live vaccine strain Francisella tularensis LVS stimulate T cells from naturally infected individuals. J Clin Microbiol. 1990;28(1):43-48.

64. Conlan JW, Shen H, Webb A, Perry MB. Mice vaccinated with the O-antigen of Francisella tularensis LVS lipopolysaccharide conjugated to bovine serum albumin develop varying degrees of protective immunity against systemic or aerosol challenge with virulent type A and type B strains of the pathogen. Vaccine. 2002;20(29-30):3465-3471.

65. Fulop M, Manchee R, Titball R. Role of lipopolysaccharide and a major outer membrane protein from Francisella tularensis in the induction of immunity against tularemia. Vaccine. 1995;13(13):1220-1225.

66. Huntley JF, Conley PG, Rasko DA, Hagman KE, Apicella MA, Norgard MV. Native outer membrane proteins protect mice against pulmonary challenge with virulent type A Francisella tularensis. Infect Immun. 2008;76(8):3664-3671.

67. Thomas RM, Titball RW, Oyston PC, et al. The immunologically distinct $\mathrm{O}$ antigens from Francisella tularensis subspecies tularensis and Francisella novicida are both virulence determinants and protective antigens. Infect Immun. 2007;75(1):371-378.

68. Apicella MA, Post DM, Fowler AC, et al. Identification, characterization and immunogenicity of an O-antigen capsular polysaccharide of Francisella tularensis. PLoS One. 2010;5(7):e11060.

69. Chiavolini D, Weir S, Murphy JR, Wetzler LM. Neisseria meningitidis PorB, a toll-like receptor 2 ligand, improves the capacity of Francisella tularensis lipopolysaccharide to protect mice against experimental tularemia. Clin Vaccine Immunol. 2008;15(9):1322-1329.

70. Prior JL, Prior RG, Hitchen PG, et al. Characterization of the $\mathrm{O}$ antigen gene cluster and structural analysis of the $\mathrm{O}$ antigen of Francisella tularensis subsp. tularensis. J Med Microbiol. 2003;52(pt 10):845-851.

71. Golovliov I, Ericsson M, Akerblom L, Sandstrom G, Tarnvik A, Sjostedt A. Adjuvanticity of ISCOMs incorporating a T cell-reactive lipoprotein of the facultative intracellular pathogen Francisella tularensis. Vaccine. 1995;13(3):261-267.

72. Ashtekar AR, Katz J, Xu Q, Michalek SM. A mucosal subunit vaccine protects against lethal respiratory infection with Francisella tularensis LVS. PLoS One. 2012;7(11):e50460.

73. Hickey AJ, Hazlett KR, Kirimanjeswara GS, Metzger DW. Identification of Francisella tularensis outer membrane protein A (FopA) as a protective antigen for tularemia. Vaccine. 2011;29(40):6941-6947.

74. da Silva AJ, Zangirolami TC, Novo-Mansur MT, Giordano Rde C, Martins EA. Live bacterial vaccine vectors: an overview. Braz J Microbiol. 2015;45(4):1117-1129.

75. Ura T, Okuda K, Shimada M. Developments in viral vector-based vaccines. Vaccines (Basel). 2014;2(3):624-641.

76. Shahabi V, Maciag PC, Rivera S, Wallecha A. Live, attenuated strains of Listeria and Salmonella as vaccine vectors in cancer treatment. Bioeng Bugs. 2010;1(4):235-243.

77. Bermudez-Humaran LG, Kharrat P, Chatel JM, Langella P. Lactococci and lactobacilli as mucosal delivery vectors for therapeutic proteins and DNA vaccines. Microb Cell Fact. 2011;10(suppl 1):S4.

78. Mielcarek N, Debrie AS, Raze D, et al. Attenuated Bordetella pertussis: new live vaccines for intranasal immunisation. Vaccine. 2006;24(suppl 2): S2-S54.

79. Matsuo K, Yasutomi Y. Mycobacterium bovis Bacille Calmette-Guerin as a vaccine vector for global infectious disease control. Tuberc Res Treat. 2011;2011:574591.

80. Jia Q, Lee BY, Clemens DL, Bowen RA, Horwitz MA. Recombinant attenuated Listeria monocytogenes vaccine expressing Francisella tularensis $\mathrm{IglC}$ induces protection in mice against aerosolized type A F. tularensis. Vaccine. 2009;27(8):1216-1229.

81. Fulop M, Manchee R, Titball R. Role of two outer membrane antigens in the induction of protective immunity against Francisella tularensis strains of different virulence. FEMS Immunol Med Microbiol. 1996;13(3):245-247. 
82. Banik S, Mansour AA, Suresh RV, et al. Development of a multivalent subunit vaccine against tularemia using tobacco mosaic virus (TMV) based delivery system. PLoS One. 2015;10(6):e0130858.

83. Iglesias BV, Bitsaktsis C, Pham G, et al. Multiple mechanisms mediate enhanced immunity generated by mAb-inactivated $F$. tularensis immunogen. Immunol Cell Biol. 2013;91(2):139-148.

84. Bitsaktsis C, Iglesias BV, Li Y, et al. Mucosal immunization with an unadjuvanted vaccine that targets Streptococcus pneumoniae PspA to human Fcgamma receptor type I protects against pneumococcal infection through complement- and lactoferrin-mediated bactericidal activity. Infect Immun. 2012;80(3):1166-1180.

85. Geier H, Celli J. Phagocytic receptors dictate phagosomal escape and intracellular proliferation of Francisella tularensis. Infect Immun. 2011;79(6):2204-2214.

86. Bitsaktsis C, Babadjanova Z, Gosselin EJ. In vivo mechanisms involved in enhanced protection utilizing an Fc receptor-targeted mucosal vaccine platform in a bacterial vaccine and challenge model. Infect Immun. 2015;83(1):77-89.

87. Suresh RV, Ma Z, Sunagar R, et al. Preclinical testing of a vaccine candidate against tularemia. PLoS One. 2015;10(4):e0124326.

88. Franz BJ, LiY, Bitsaktsis C, et al. Downmodulation of vaccine-induced immunity and protection against the intracellular bacterium Francisella tularensis by the inhibitory receptor FcgammaRIIB. J Immunol Res. 2015;2015:840842.

89. Liu MA. DNA vaccines: an historical perspective and view to the future. Immunol Rev. 2011;239(1):62-84.

90. Gregory SH, Mott S, Phung J, et al. Epitope-based vaccination against pneumonic tularemia. Vaccine. 2009;27(39):5299-5306.

91. Rotem S, Cohen O, Bar-Haim E, Bar-On L, Ehrlich S, Shafferman A. Protective immunity against lethal F. tularensis holarctica LVS provided by vaccination with selected novel CD8+ T cell epitopes. PLoS One. 2014;9(1):e85215.

92. Molins CR, Delorey MJ, Yockey BM, et al. Virulence differences among Francisella tularensis subsp. tularensis clades in mice. PLoS One. 2010;5(4):e10205.

93. Molins CR, Delorey MJ, Yockey BM, et al. Virulence difference between the prototypic Schu S4 strain (A1a) and Francisella tularensis A1a, A1b, A2 and type B strains in a murine model of infection. BMC Infect Dis. 2014;14:67.

94. Twine SM, Shen H, Kelly JF, Chen W, Sjostedt A, Conlan JW. Virulence comparison in mice of distinct isolates of type A Francisella tularensis. Microb Pathog. 2006;40(3):133-138.

95. Anderson RV, Crane DD, Bosio CM. Long lived protection against pneumonic tularemia is correlated with cellular immunity in peripheral, not pulmonary, organs. Vaccine. 2010;28(40):6562-6572.

96. Chen W, Shen H, Webb A, KuoLee R, Conlan JW. Tularemia in BALB/c and C57BL/6 mice vaccinated with Francisella tularensis LVS and challenged intradermally, or by aerosol with virulent isolates of the pathogen: protection varies depending on pathogen virulence, route of exposure, and host genetic background. Vaccine. 2003;21(25-26):3690-3700.

97. Eigelsbach HT, Braun W, Herring RD. Studies on the variation of bacterium tularense. J Bacteriol. 1951;61(5):557-569.

98. Soni S, Ernst RK, Muszynski A, et al. Francisella tularensis blue-gray phase variation involves structural modifications of lipopolysaccharide o-antigen, core and lipid a and affects intramacrophage survival and vaccine efficacy. Front Microbiol. 2010;1:129.

99. Zarrella TM, Singh A, Bitsaktsis C, et al. Host-adaptation of Francisella tularensis alters the bacterium's surface-carbohydrates to hinder effectors of innate and adaptive immunity. PLoS One. 2011;6(7):e22335.

100. Eickhoff TC. The current status of BCG immunization against tuberculosis. Annu Rev Med. 1977;28:411-423.

101. Venkataswamy MM, Goldberg MF, Baena A, Chan J, Jacobs WR Jr, Porcelli SA. In vitro culture medium influences the vaccine efficacy of Mycobacterium bovis BCG. Vaccine. 2012;30(6):1038-1049.

102. Florio W, Batoni G, Esin S, et al. Influence of culture medium on the resistance and response of Mycobacterium bovis BCG to reactive nitrogen intermediates. Microbes Infect. 2006;8(2):434-441.
103. Cloete TE, de Bruyn EE. The effect of culture media on antigenic expression in sulfate-reducing bacteria. Curr Microbiol. 2001;42(5):305-309.

104. Geng T, Hahm BK, Bhunia AK. Selective enrichment media affect the antibody-based detection of stress-exposed Listeria monocytogenes due to differential expression of antibody-reactive antigens identified by protein sequencing. J Food Prot. 2006;69(8):1879-1886.

105. Geng T, Kim KP, Gomez R, et al. Expression of cellular antigens of Listeria monocytogenes that react with monoclonal antibodies C11E9 and EM-7G1 under acid-, salt- or temperature-induced stress environments. J Appl Microbiol. 2003;95(4):762-772.

106. Hahm BK, Bhunia AK. Effect of environmental stresses on antibodybased detection of Escherichia coli O157:H7, Salmonella enterica serotype enteritidis and Listeria monocytogenes. J Appl Microbiol. 2006;100(5):1017-1027.

107. Walsh EJ, Moran AP. Influence of medium composition on the growth and antigen expression of Helicobacter pylori. J Appl Microbiol. 1997;83(1):67-75.

108. Hazlett KR, Caldon SD, McArthur DG, et al. Adaptation of Francisella tularensis to the mammalian environment is governed by cues which can be mimicked in vitro. Infect Immun. 2008;76(10):4479-4488.

109. Singh A, Rahman T, Malik M, et al. Discordant results obtained with Francisella tularensis during in vitro and in vivo immunological studies are attributable to compromised bacterial structural integrity. PLoS One. 2013;8(3):e58513.

110. Loegering DJ, Drake JR, Banas JA, et al. Francisella tularensis LVS grown in macrophages has reduced ability to stimulate the secretion of inflammatory cytokines by macrophages in vitro. Microb Pathog. 2006;41(6):218-225.

111. Garcia-Pelayo MC, Bachy VS, Kaveh DA, Hogarth PJ. BALB/c mice display more enhanced BCG vaccine induced Th1 and Th17 response than C57BL/6 mice but have equivalent protection. Tuberculosis. 2015;95(1):48-53

112. Hume EB, Cole N, Khan S, et al. A Staphylococcus aureus mouse keratitis topical infection model: cytokine balance in different strains of mice. Immunol Cell Biol. 2005;83(3):294-300.

113. Barbi J, Brombacher F, Satoskar AR. T cells from Leishmania majorsusceptible BALB/c mice have a defect in efficiently up-regulating CXCR3 upon activation. J Immunol. 2008;181(7):4613-4620.

114. Twine S, Shen H, Harris G, et al. BALB/c mice, but not C57BL/6 mice immunized with a $\Delta \mathrm{clpB}$ mutant of Francisella tularensis subspecies tularensis are protected against respiratory challenge with wild-type bacteria: association of protection with post-vaccination and post-challenge immune responses. Vaccine. 2012;30(24): 3634-3645.

115. Huffnagle GB, Boyd MB, Street NE, Lipscomb MF. IL-5 is required for eosinophil recruitment, crystal deposition, and mononuclear cell recruitment during a pulmonary Cryptococcus neoformans infection in genetically susceptible mice (C57BL/6). J Immunol. 1998;160(5):2393-2400.

116. Hoag KA, Street NE, Huffnagle GB, Lipscomb MF. Early cytokine production in pulmonary Cryptococcus neoformans infections distinguishes susceptible and resistant mice. Am J Respir Cell Mol Biol. 1995;13(4):487-495.

117. De Pascalis R, Mittereder L, Chou AY, Kennett NJ, Elkins KL. Francisella tularensis vaccines elicit concurrent protective Tand B-cell immune responses in BALB/cByJ mice. PLoS One. 2015;10(5):e0126570.

118. Conlan JW, Shen H, Golovliov I, et al. Differential ability of novel attenuated targeted deletion mutants of Francisella tularensis subspecies tularensis strain SCHU S4 to protect mice against aerosol challenge with virulent bacteria: effects of host background and route of immunization. Vaccine. 2010;28(7):1824-1831.

119. Aronova NV, Pavlovich NV. [Comparative analysis of the immune response of a rabbit to antigens to live and killed Francisella species bacteria]. Mol Gen Mikrobiol Virusol. 2001;2:26-30. Russian.

120. Rick Lyons C, Wu TH. Animal models of Francisella tularensis infection. Ann N Y Acad Sci. 2007;1105:238-265. 
121. Nelson M, Lever MS, Savage VL, et al. Establishment of lethal inhalational infection with Francisella tularensis (tularaemia) in the common marmoset (Callithrix jacchus). Int J Exp Pathol. 2009;90(2): 109-118.

122. Kadioglu A, Cuppone AM, Trappetti C, et al. Sex-based differences in susceptibility to respiratory and systemic pneumococcal disease in mice. J Infect Dis. 2011;204(12):1971-1979.

123. Shankar J, Restrepo A, Clemons KV, Stevens DA. Hormones and the resistance of women to paracoccidioidomycosis. Clin Microbiol Rev. 2011;24(2):296-313.

124. Frisancho-Kiss S, Nyland JF, Davis SE, et al. Sex differences in coxsackievirus B3-induced myocarditis: IL-12Rbeta1 signaling and IFN-gamma increase inflammation in males independent from STAT4. Brain Res. 2006;1126(1):139-147.

125. Rohrbach BW, Westerman E, Istre GR. Epidemiology and clinical characteristics of tularemia in Oklahoma, 1979 to 1985. South Med J. 1991;84(9):1091-1096.

126. Sunagar R, Kumar S, Franz BJ, Gosselin EJ. 2016. Vaccination evokes gender-dependent protection against tularemia infection in C57BL6/ Tac mice. Vaccine. In Press 2016.

127. Engler RJ, Nelson MR, Klote MM, et al. Half- vs full-dose trivalent inactivated influenza vaccine (2004-2005): age, dose, and sex effects on immune responses. Arch Intern Med. 2008;168(22):2405-2414.

128. Cook IF. Sexual dimorphism of humoral immunity with human vaccines. Vaccine. 2008;26(29-30):3551-3555.

129. Lorenzo ME, Hodgson A, Robinson DP, Kaplan JB, Pekosz A, Klein SL. Antibody responses and cross protection against lethal influenza A viruses differ between the sexes in C57BL/6 mice. Vaccine. 2011;29(49):9246-9255.

130. Daniels CW, Belosevic M. Serum antibody responses by male and female C57B1/6 mice infected with Giardia muris. Clin Exp Immunol. 1994;97(3):424-429.

131. Griffin AJ, Crane DD, Wehrly TD, Bosio CM. Successful protection against tularemia in $\mathrm{C} 57 \mathrm{BL} / 6$ mice is correlated with expansion of Francisella tularensis-specific effector T cells. Clin Vaccine Immunol. 2015;22(1):119-128.

132. Barrigan LM, Tuladhar S, Brunton JC, et al. Infection with Francisella tularensis LVS clpB leads to an altered yet protective immune response. Infect Immun. 2013;81(6):2028-2042.

133. Jia Q, Lee BY, Bowen R, Dillon BJ, Som SM, Horwitz MA. A Francisella tularensis live vaccine strain (LVS) mutant with a deletion in capB, encoding a putative capsular biosynthesis protein, is significantly more attenuated than LVS yet induces potent protective immunity in mice against $F$. tularensis challenge. Infect Immun. 2010;78(10):4341-4355.

134. Golovliov I, Twine SM, Shen H, Sjostedt A, Conlan W. A $\Delta$ clpB mutant of Francisella tularensis subspecies holarctica strain, FSC200, is a more effective live vaccine than $F$. tularensis LVS in a mouse respiratory challenge model of tularemia. PLoS One. 2013;8(11):e78671.

135. Straskova A, Spidlova P, Mou S, et al. Francisella tularensis type B $\triangle \mathrm{dsbA}$ mutant protects against type A strain and induces strong inflammatory cytokine and Th1-like antibody response in vivo. Pathog Dis. 2015;73(8):ftv058.
136. Sebastian S, Dillon ST, Lynch JG, et al. A defined O-antigen polysaccharide mutant of Francisella tularensis live vaccine strain has attenuated virulence while retaining its protective capacity. Infect Immun. 2007;75(5):2591-2602.

137. Kim TH, Pinkham JT, Heninger SJ, Chalabaev S, Kasper DL. Genetic modification of the O-polysaccharide of Francisella tularensis results in an avirulent live attenuated vaccine. J Infect Dis. 2012;205(7):1056-1065.

138. Sanapala S, Yu JJ, Murthy AK, et al. Perforin- and granzymemediated cytotoxic effector functions are essential for protection against Francisella tularensis following vaccination by the defined F. tularensis subsp. novicida $\Delta$ fopC vaccine strain. Infect Immun 2012;80(6):2177-2185.

139. Chu P, Cunningham AL, Yu JJ, et al. Live attenuated Francisella novicida vaccine protects against Francisella tularensis pulmonary challenge in rats and non-human primates. PLoS Pathog. 2014;10(10):e1004439.

140. Signarovitz AL, Ray HJ, Yu JJ, et al. Mucosal immunization with live attenuated Francisella novicida U112 $\Delta$ iglB protects against pulmonary F. tularensis SCHU S4 in the Fischer 344 rat model. PLoS One. 2012;7(10):e47639.

141. Cunningham AL, Dang KM, Yu JJ, et al. Enhancement of vaccine efficacy by expression of a TLR5 ligand in the defined live attenuated Francisella tularensis subsp. novicida strain U112 AiglB:fljB. Vaccine. 2014;32(40):5234-5240.

142. Qin A, Scott DW, Thompson JA, Mann BJ. Identification of an essential Francisella tularensis subsp. tularensis virulence factor. Infect Immun. 2009;77(1):152-161.

143. Rockx-Brouwer D, Chong A, Wehrly TD, et al. Low dose vaccination with attenuated Francisella tularensis strain SchuS4 mutants protects against tularemia independent of the route of vaccination. PLoS One. 2012;7(5): e37752.

144. Michell SL, Dean RE, Eyles JE, et al. Deletion of the Bacillus anthracis capB homologue in Francisella tularensis subspecies tularensis generates an attenuated strain that protects mice against virulent tularaemia. J Med Microbiol. 2010;59(pt 11):1275-1284.

145. Twine S, Bystrom M, Chen W, et al. A mutant of Francisella tularensis strain SCHU S4 lacking the ability to express a 58-kilodalton protein is attenuated for virulence and is an effective live vaccine. Infect Immun 2005;73(12):8345-8352.

146. Ireland PM, LeButt H, Thomas RM, Oyston PC. A Francisella tularensis SCHU S4 mutant deficient in gamma-glutamyltransferase activity induces protective immunity: characterization of an attenuated vaccine candidate. Microbiology. 2011;157(pt 11):3172-3179.

147. Reed DS, Smith LP, Cole KS, Santiago AE, Mann BJ, Barry EM. Live attenuated mutants of Francisella tularensis protect rabbits against aerosol challenge with a virulent type A strain. Infect Immun . 2014;82(5):2098-2105.
Vaccine: Development and Therapy

\section{Publish your work in this journal}

Vaccine: Development and Therapy is an international, peer-reviewed, open access journal that spans the spectrum of vaccine design and development through to clinical applications. The journal is characterized by the rapid reporting of application notes, reviews, original research and clinical studies in all therapeutic areas. Clinical outcomes, patient safety,

\section{Dovepress}

and programs for the development and effective, safe, and sustained use of vaccines will be a feature of the journal. The manuscript management system is completely online and includes a very quick and fair peer-review system. Visit http://www.dovepress.com/testimonials.php to read real quotes from published authors. 